\title{
Production of Ligninolytic Enzymes by Oyster Mushroom Pleurotus ostreatus (Jacq.:Fr.) P. Kumm. Under Different Nutritional Conditions
}

\author{
Nona Mikiashvili, Solomon P. Wasser, E̋ Eviatar Nevo \\ Institute of Evolution, University of Haifa, Mt. Carmel, 31905 Haifa, Israel
}

One of the effective methods for regulating and increasing the quantity of ligninolytic enzymes is the addition of the appropriate inducers to the nutrient medium. The ligninolytic enzymes of some white-rot fungi are synthesized only after the primary growth phase in response to nitrogen and carbon limitations in the medium. In the screening program, Pleurotus ostreatus appeared to be one of the best producers of extracellular laccase (Lac) and manganese peroxidase $(\mathrm{MgP})$. Therefore, we compared the effect of different carbon and nitrogen sources, including lignocellulosic substrates, on $P$. ostreatus 98 oxidative enzyme production.

The secretion of $\mathrm{Lac}, \mathrm{MgP}$, and versatile peroxidase (VP) were significantly dependent on 11 types of carbon sources when species were grown in a medium with $2 \mathrm{~g} / \mathrm{L} \mathrm{NH}_{4} \mathrm{NO}_{3}$. Mandarin peels, which were used as one of the possible substrates, ensured very high yields of $\mathrm{Lac}(2375.5 \mathrm{U} / \mathrm{L})$. Increasing its concentration in the nutrition medium from $20 \mathrm{~g} / \mathrm{L}$ to $40 \mathrm{~g} / \mathrm{L}$ resulted in a more than six-fold increase in Lac activity. Carboxylmethylcellulose, gluconic acid, glucose, and cellobiose $(10 \mathrm{~g} / \mathrm{L})$ appeared to be poor growth substrates for Lac production. Moreover, results of this study showed that the activity of the enzyme was at its lowest level on medium containing avicel and mannitol.
Lignin degradation of $P$. ostreatus 98 on culture media with $10 \mathrm{~g} / \mathrm{L}$ glucose and 11 types of nitrogen sources $(0.5 \mathrm{~g} / \mathrm{L})$ was suppressed. This species showed high Lac activity in the presence of peptone, kazein acid, and corn step liquor (887.1 U/L, 802.3 $\mathrm{U} / \mathrm{L}$, and $674.3 \mathrm{U} / \mathrm{L}$, respectively). In contrast, medium with $\mathrm{NaNO}_{3}, \mathrm{NH}_{4} \mathrm{NO}_{3}$, and $\left(\mathrm{NH}_{4}\right)_{2} \mathrm{SO}_{4}$ inhibited this enzyme accumulation.

Secretion of $\mathrm{VP}$ and $\mathrm{MnP}$ by the investigated strain was comparatively low. Adding different carbon sources to the medium caused variation of VP activity from $0.24 \mathrm{U} / \mathrm{L}$ (medium with xylan) to $32.4 \mathrm{U} / \mathrm{L}$ (medium with mandarine peels). The results demonstrated that $\mathrm{MnP}$ activity was almost two-fold lower than VP activity on all of the used sources. The content of kazein acid and corn step liquor exerted the most favorable influence on the activity of $\mathrm{VP}$ and $\mathrm{MnP}$. On the other hand, $\mathrm{NH}_{4} \mathrm{NO}_{3}, \mathrm{NH}_{4} \mathrm{Cl}$, and $\left(\mathrm{NH}_{4}\right)_{2} \mathrm{SO}_{4}$ were rather poor nitrogen sources for the production of these peroxidases.

In conclusion, it was shown that the synthesis of Lac, MnP, and VP by P. ostreatus 98 differed in various nutritional conditions. Among the different carbon and nitrogen sources, mandarine peels and peptone were optimal substrates for high production of the investigated enzymes. 